\title{
THE EFFECT OF DIHYDROERGOCORNINE ON THE PULMO- NARY RESPONSE TO METHACHOLINE AND HISTAMINE IN SUBJECTS WITH BRONCHIAL ASTHMA
}

\author{
BY JOHN J. CURRY,1 JOB E. FUCHS, AND SAMUEL E. LEARD \\ (From the Evans Memorial, Massachusetts Memorial Hospitals, and the Department of Medi- \\ cine, Boston University School of Medicine, Boston)
}

(Submitted for publication September 26, 1949; accepted, December 5, 1949)

Little is known about the fundamental causes of bronchial asthma and the alterations in pulmonary physiology leading to an attack. The abnormal reaction of the tracheobronchial tree to histamine and to cholinergic substances such as methacholine and pilocarpine has been studied in detail (1-3). The parenteral administration of these drugs brings about a sharp reduction in maximum minute ventilation and vital capacity associated with an evanescent asthma-like attack. The intensity of the pulmonary reaction appears to be associated with the degree of asthma (4), and may be modified by various anti-asthmatic agents such as epinephrine, Orthoxine, aminophylline, Benadryl, Pyrrolazote and hyoscyamine (5). A relationship also exists between the clinical effectiveness of anti-asthmatic agents and the degree of protection they afford against the pulmonary response to injected methacholine and histamine (6).

It is not clear why the tracheobronchial tree in asthmatic subjects reacts in an abnormal manner. It is not likely that infection of the mucous membranes in the lungs is the sole cause since some of our reactive subjects had not had an attack of asthma in over 20 years, and some had no history of bronchitis or other pulmonary infection. Moreover, in a few subjects with hay fever who had never suffered with asthma, the injection of methacholine produced a notable reduction in vital capacity (2). The clinical improvement reported in some patients after surgical interruption of the para-sympathetic and sympathetic pathways of the lungs $(7,8)$ suggests that a reflex mechanism may be involved. Further support of this idea is furnished by studies carried out in conjunction with Dr. George Whitelaw in which bilateral procaine block of stellate ganglia modified the pulmonary response to methacholine and histamine (9). It was felt worthwhile, therefore, to observe the effect of a sympatholytic drug in similar studies.

1 Present address: Georgetown University Hospital, Washington, D. C.
Dihydroergocornine, a dihydrogenated alkaloid of ergot, was chosen because it is relatively nontoxic, short-acting and may be administered by mouth as well as by vein (10).

\section{MATERIAL AND METHODS}

The method of study has been reported elsewhere in detail $(1,6)$. A 9-liter Benedict-Roth type of spirometer was used. It was equipped with special low resistance valves and a recording ventilometer (11) that measured inspiratory volume only. The soda lime container was removed. Subjects came to the laboratory in a state relatively free from asthma. Three to six control measurements of the vital capacity and maximum minute ventilation were recorded on a rapidly moving drum. The maximum ventilatory effort was made for 15 seconds with the patient choosing his own rate and depth of respiration after the method of Hermannsen which has been discussed in detail by Cournand, Richards and Darling (12). Normal values for this method are approximately 150 liters per minute for normal males and 100 liters per minute for normal females. The spirometer was flushed with air five times after each set of determinations.

An evanescent asthma-like attack with reduction in vital capacity of about $1000 \mathrm{ml}$. was induced by the intramuscular injection of $1-6 \mathrm{mg}$. of methacholine chloride and in a few instances with the intravenous injection of 0.01-0.04 mg. of histamine base. When the vital capacity and maximum minute ventilation had returned to approximately the pre-injection levels, $0.25-0.75 \mathrm{mg}$. of dihydroergocornine was administered intravenously, except in two cases. In these two cases $0.4 \mathrm{mg}$. of the drug was given by nebulization utilizing a De Vilbiss No. 40 nebulizer with an oxygen flow adjusted to read 6-8 liters per minute. The dosage of dihydroergocornine was adjusted to produce slight postural hypotension and usually nasal stuffiness. Vital capacity and maximum minute ventilation were again determined, and at intervals, usually of 15 minutes, identical doses of methacholine or histamine were injected and the effect on the pulmonary function tests again recorded. The degree of protection afforded by dihydroergocornine may be expressed by the following formula :

$$
\frac{\frac{D c}{V c}-\frac{D t}{V t}}{\frac{D c}{V c}} \times 100=P
$$


JOHN J. CURRY, JOB E. FUCHS, AND SAMUEL E. LEARD

TABLE I

Effect of dihydroergocornine on the pulmonary reaction to methacholine

\begin{tabular}{|c|c|c|c|c|c|c|c|c|}
\hline & \multirow{2}{*}{$\begin{array}{l}\text { Age } \\
\text { Sex }\end{array}$} & & \multicolumn{2}{|c|}{ Control studies } & \multicolumn{4}{|c|}{ After dihydroergocornine } \\
\hline & & & Resting & $\begin{array}{l}\text { After } \\
\text { metha- } \\
\text { choline }\end{array}$ & Dose* & Resting & $\begin{array}{l}\text { After } \\
\text { metha- } \\
\text { choline }\end{array}$ & $\begin{array}{l}\text { Per cent } \\
\text { protection }\end{array}$ \\
\hline R. G. & $\begin{array}{l}30 \\
\mathbf{M}\end{array}$ & $\begin{array}{l}\text { V.C. in } \mathrm{ml} . \dagger \\
\mathrm{M} . \mathrm{V} \text {. in } 1 / \mathrm{min} .\end{array}$ & $\begin{array}{r}4285 \ddagger \\
-56.4\end{array}$ & $\begin{array}{c}3177 \\
39.7\end{array}$ & $\begin{array}{c}m g . \\
0.5^{*}\end{array}$ & $\begin{array}{c}4075 \\
48.1\end{array}$ & $\begin{array}{r}3668 \\
42.8\end{array}$ & $\begin{array}{l}62 \\
63\end{array}$ \\
\hline J. C. & $\begin{array}{l}36 \\
\mathbf{M}\end{array}$ & $\begin{array}{l}\text { V.C. in } \mathrm{ml} \text {. } \\
\text { M.V. in } 1 / \mathrm{min} .\end{array}$ & $\begin{array}{l}5047 \\
55.4\end{array}$ & $\begin{array}{l}3428 \\
51.2\end{array}$ & 0.25 & $\begin{array}{l}4556 \\
62.7\end{array}$ & $\begin{array}{l}3699 \\
56.4\end{array}$ & $\begin{array}{r}42 \\
-24\end{array}$ \\
\hline W. B. & $\begin{array}{l}47 \\
M\end{array}$ & $\begin{array}{l}\text { V.C. in } \mathrm{ml} \\
\mathrm{M} . \mathrm{V} \text {. in } 1 / \mathrm{min} \text {. }\end{array}$ & $\begin{array}{l}3406 \\
85.7\end{array}$ & $\begin{array}{c}2759 \\
69.0\end{array}$ & 0.75 & $\begin{array}{c}4159 \\
95.1 \\
4085 \\
96.1\end{array}$ & $\begin{array}{c}3919 \\
88.9 \\
3511 \\
88.9\end{array}$ & $\begin{array}{l}70 \\
67 \\
26 \\
62\end{array}$ \\
\hline J.S. & $\begin{array}{l}51 \\
\mathbf{M}\end{array}$ & $\begin{array}{l}\text { V.C. in } \mathrm{ml} \\
\mathrm{M} . \mathrm{V} \text {. in } 1 / \mathrm{min} \text {. }\end{array}$ & $\begin{array}{l}2362 \\
48.1\end{array}$ & $\begin{array}{l}1765 \\
35.5\end{array}$ & 0.25 & $\begin{array}{r}2194 \\
39.7\end{array}$ & $\begin{array}{l}1943 \\
35.5\end{array}$ & $\begin{array}{l}55 \\
59\end{array}$ \\
\hline J.S. & $\begin{array}{l}32 \\
\mathbf{M}\end{array}$ & $\begin{array}{l}\text { V.C. in } \mathrm{ml} \text {. } \\
\text { M.V. in } 1 / \mathrm{min} \text {. }\end{array}$ & $\begin{array}{l}5152 \\
104.5\end{array}$ & $\begin{array}{l}4358 \\
69.0\end{array}$ & 0.25 & $\begin{array}{c}4713 \\
72.1\end{array}$ & $\begin{array}{r}4483 \\
65\end{array}$ & $\begin{array}{l}68 \\
75\end{array}$ \\
\hline T. H. & $\begin{array}{l}19 \\
M\end{array}$ & $\begin{array}{l}\text { V.C. in } \mathrm{ml} \text {. } \\
\text { M.V. in } 1 / \mathrm{min} .\end{array}$ & $\begin{array}{l}4473 \\
91.0\end{array}$ & $\begin{array}{r}2686 \\
52.3\end{array}$ & 0.45 & $\begin{array}{c}4525 \\
22.3 \\
4681 \\
123.3\end{array}$ & $\begin{array}{c}4389 \\
98.2 \\
4598 \\
94.1\end{array}$ & $\begin{array}{l}93 \\
55 \\
95 \\
50\end{array}$ \\
\hline N. A. & $\stackrel{35}{F}$ & $\begin{array}{l}\text { V.C. in } \mathrm{ml} \\
\mathrm{M} . \mathrm{V} \text {. in } 1 / \mathrm{min} .\end{array}$ & $\begin{array}{l}4618 \\
113.9\end{array}$ & $\begin{array}{l}3365 \\
55.4\end{array}$ & 0.25 & $\begin{array}{l}4556 \\
83.6\end{array}$ & $\begin{array}{l}4504 \\
77.3\end{array}$ & $\begin{array}{l}96 \\
85\end{array}$ \\
\hline J. M. & 28 & $\begin{array}{l}\text { V.C. in } \mathrm{ml} \text {. } \\
\text { M.V. in } 1 / \mathrm{min} \text {. }\end{array}$ & $\begin{array}{l}5766 \\
83.6\end{array}$ & $\begin{array}{r}5225 \\
76.2\end{array}$ & 0.25 & $\begin{array}{r}5852 \\
89.9\end{array}$ & $\begin{array}{l}5539 \\
79.4\end{array}$ & $\begin{array}{r}44 \\
-33\end{array}$ \\
\hline R. L. & $\begin{array}{l}42 \\
M\end{array}$ & $\begin{array}{l}\text { V.C. in } \mathrm{ml} \\
\text { M.V. in } 1 / \mathrm{min} \text {. }\end{array}$ & $\begin{array}{r}3762 \\
89.9\end{array}$ & $\begin{array}{c}2539 \\
51.2\end{array}$ & 0.25 & $\begin{array}{c}3605 \\
75.2 \\
3658 \\
66.9\end{array}$ & $\begin{array}{c}3114 \\
46.0 \\
2759 \\
60.6\end{array}$ & $\begin{array}{r}59 \\
9 \\
24 \\
78\end{array}$ \\
\hline H. D. & $\begin{array}{l}33 \\
M\end{array}$ & $\begin{array}{l}\text { V.C. in } \mathrm{ml} \text {. } \\
\text { M.V. in } 1 / \mathrm{min} \text {. }\end{array}$ & $\begin{array}{c}2518 \\
42.8\end{array}$ & $\begin{array}{r}2236 \\
29.3\end{array}$ & $0.5^{*}$ & $\begin{array}{c}2529 \\
40.7\end{array}$ & $\begin{array}{r}2278 \\
31.4\end{array}$ & $\begin{array}{r}9 \\
28\end{array}$ \\
\hline
\end{tabular}

* Doses of dihydroergocornine marked with asterisk were given by nebulization. Protection studies were made 15 minutes and in some instances 30 minutes after dihydroergocornine was administered.

+ V.C. = Vital capacity; M.V. = maximum ventilation.

$\ddagger$ Plain numbers represent vital capacity in ml., numbers in italics represent maximum ventilation in liters per minute.

ABLE II

Effect of dihydroergocornine on the pulmonary reaction to histamine

\begin{tabular}{|c|c|c|c|c|c|c|c|c|}
\hline & \multirow{2}{*}{ Age } & & \multicolumn{2}{|c|}{ Control studies } & \multicolumn{4}{|c|}{ After dihydroergocornine } \\
\hline & & & Resting & $\underset{\text { histamine }}{\text { After }}$ & Dose & Resting & $\underset{\text { histamine }}{\text { After }}$ & $\begin{array}{l}\text { Per cent } \\
\text { protection }\end{array}$ \\
\hline R. G. & $\begin{array}{l}30 \\
\mathbf{M}\end{array}$ & $\begin{array}{l}\text { V.C. in ml. }{ }^{\dagger} . \mathrm{V} \text {. in } 1 / \mathrm{min} .\end{array}$ & $\begin{array}{l}4149 \\
48.1 \ddagger\end{array}$ & $\begin{array}{l}2748 \\
40.7\end{array}$ & $\begin{array}{l}m g . \\
0.5^{*}\end{array}$ & $\begin{array}{l}4285 \\
50.2\end{array}$ & $\begin{array}{r}2549 \\
41.8\end{array}$ & $\begin{array}{l}-21 \\
-8\end{array}$ \\
\hline J. C. & $\begin{array}{l}36 \\
\mathbf{M}\end{array}$ & $\begin{array}{l}\text { V.C. in } \mathrm{ml} . \\
\mathrm{M} . \mathrm{V} \text {. in } 1 / \mathrm{min} .\end{array}$ & $\begin{array}{l}5016 \\
71.1\end{array}$ & $\begin{array}{l}4305 \\
62.7\end{array}$ & 0.25 & $\begin{array}{r}5016 \\
69\end{array}$ & 4681 & 53 \\
\hline J. M. & $\begin{array}{l}28 \\
\mathbf{M}\end{array}$ & $\begin{array}{l}\text { V.C. in ml. } \\
\text { M.V. in } 1 / \text { min. }\end{array}$ & $\begin{array}{r}5784 \\
95.1\end{array}$ & $\begin{array}{l}5413 \\
73.2\end{array}$ & 0.25 & $\begin{array}{l}5800 \\
83.6\end{array}$ & $\begin{array}{l}5413 \\
71.1\end{array}$ & $\begin{array}{r}0 \\
30\end{array}$ \\
\hline M. M. & $\stackrel{27}{\mathrm{~F}}$ & $\begin{array}{l}\text { V.C. in ml. } \\
\text { M.V. in } 1 / \text { min. }\end{array}$ & $\begin{array}{l}3103 \\
57.5\end{array}$ & $\begin{array}{l}2613 \\
52.3\end{array}$ & 0.25 & $\begin{array}{l}2926 \\
51.2\end{array}$ & $\begin{array}{c}2822 \\
50.2\end{array}$ & $\begin{array}{l}78 \\
78\end{array}$ \\
\hline
\end{tabular}

* Protection study was made 30 minutes after the administration of dihydroergocornine.

+ V.C. = vital capacity; M.V. = maximum ventilation.

\pm Numbers in italics represent maximum ventilation. 
where $D c=$ control decrease in vital capacity after methacoline or histamine, before administration of dihydroergocornine.

$V c=$ control vital capacity before methacholine or histamine, and before administration of dihydroergocornine.

$D t=$ decrease in vital capacity after methacholine or histamine during the particular test.

and $P=$ per cent protection.

A similar formula was used for the maximum ventilatory studies. The degree of protection probably should exceed 50 per cent in order to be significant.

\section{RESULTS AND COMMENTS}

Dihydroergocornine was given intravenously to 12 subjects with bronchial asthma; in 10 , protection studies against methacholine were performed, and in four, similar studies with histamine, (Tables I, II). No serious side reactions were experienced and no subjective changes in the asthmatic state were noted. In 10 studies with methacholine, protection varied from zero to 85 with an average of
41 per cent when maximum minute ventilation was measured, and from 9 to 96 per cent with an average of 60 per cent when vital capacity tests were employed. The most remarkable protection was found in subject T. H. (Figure 1). In this patient the resting vital capacity varied from 4409 to $4473 \mathrm{ml}$. and the maximum ventilation from 86 to 91 liters per minute. The intramuscular injection of $2 \mathrm{mg}$. of methacholine was followed by an asthma-like attack with a fall in vital capacity to $2686 \mathrm{ml}$. and the maximum ventilation to 52 liters per minute. Within 30 minutes all effects of the injection of methacholine had subsided and the values studied were again within the control range. An intravenous injection of $0.45 \mathrm{mg}$. of dihydroergocornine was followed in five minutes by an increase of $270 \mathrm{ml}$. in the vital capacity and 37 liters per minute in the maximum ventilation. Moderate postural hypotension and slight nasal stuffiness were present. At this time a repeat intramuscular

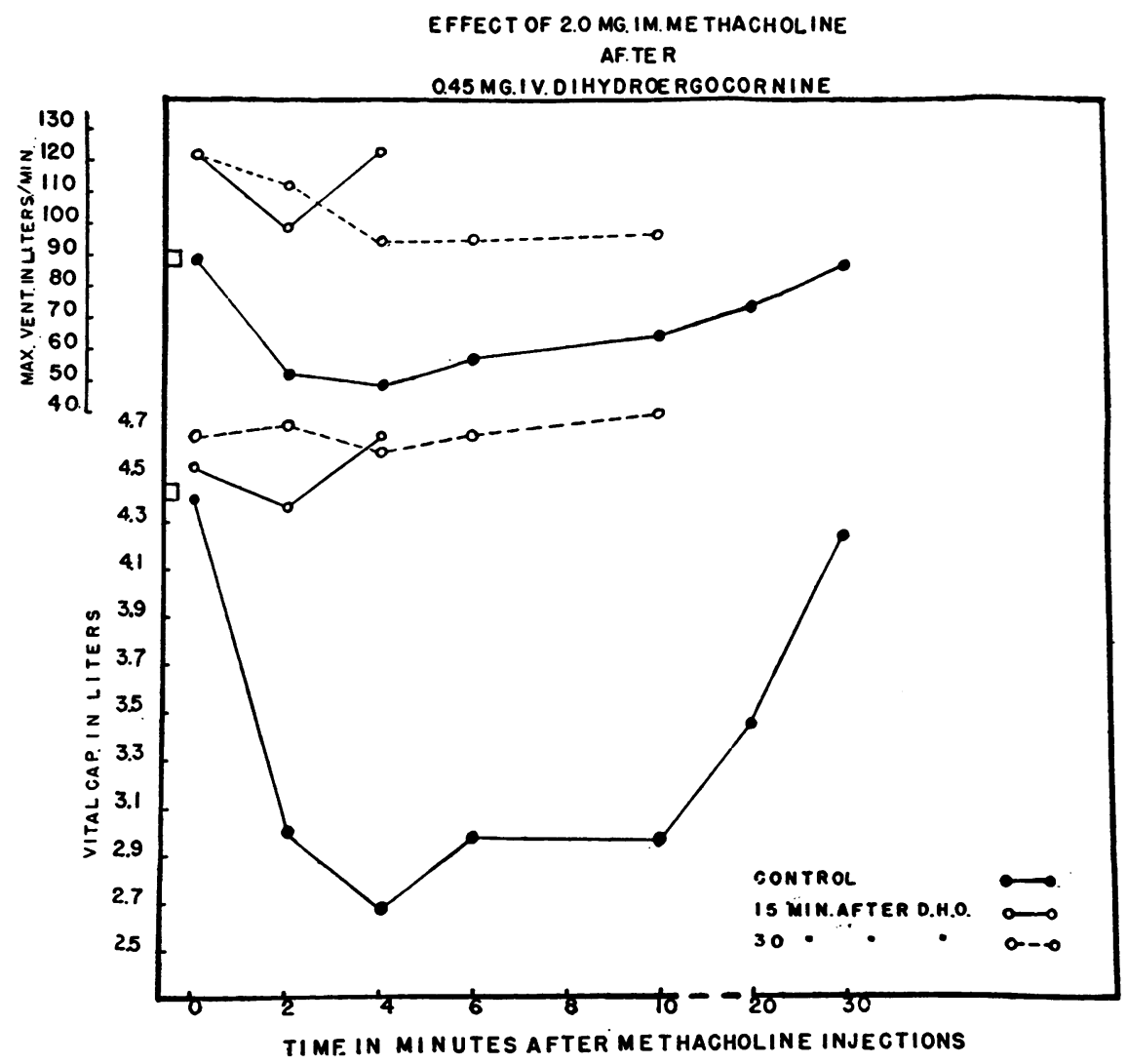

Fig. 1. The Effect of 20 Mg. Of Methacholine Injected INtramuscularly Before and After the Intravenous In Jection of 0.45 Mg. of Dimydroergocornine (DHO) 
injection of $2 \mathrm{mg}$. of methacholine resulted in only a slight decrease in both measurements and no subjective sensation in the chest. A third intramuscular injection of $2 \mathrm{mg}$. of methacholine, 30 minutes after the dihydroergocornine, likewise produced little effect. Thus, in this subject complete protection was afforded by dihydroergocornine from the subjective effects of methacholine, and almost complete protection against the reduction in vital capacity and maximum minute ventilation previously produced by the drug. In at least six cases the results were significant, in that over 50 per cent protection was achieved with both measurements of pulmonary function.

In four studies with histamine, protection varied from zero to 78 per cent with both maximum minute ventilation and vital capacity studies, and in two cases the degree of protection was significant.

Why dihydroergocornine affords protection against the action of methacholine and histamine in the tracheobronchial tree is not clear. The drug apparently does not have any notable direct anticholinergic or antihistamine action. It seems possible that the response to methacholine in the lung of asthmatic subjects may be the result of a twostage reaction. It is postulated that the first component of the reaction is a direct response of the lung to the compound. This varies with the degree of asthma and may depend in part on the presence of infection in the lung. The second component may be a reflex bronchoconstriction set up by the initial reaction of methacholine. It is suggested that this reflex is non-specific and may be set off by various types of stimuli, such as hyperventilation, irritant gases, laughing and sneezing, in addition to methacholine and histamine. The afferent or efferent limbs of the reflex might well be over the sympathetic pathways in the lungs. Thus, procaine block or surgical interruption of these pathways, or the administration of dihydroergocornine would abolish the reflex component of the methacholine reaction without affecting the direct response of the tracheobronchial tree to the drug. Thus protection afforded by dihydroergocornine against drug-induced attacks of asthma is variable and usually not complete. Similarly, in spontaneous bronchial asthma, sympathetic resection may bring about varying degrees of relief depending perhaps on the importance of the reflex com- ponent in each case of asthma. The demonstration of protection following dihydroergocornine may, therefore, indicate those cases in which sympathectomy may be of greatest benefit to the patient. The drug may also be useful in controlling spontaneous bronchial asthma. The occurrence of protection against methacholine in subject R. G. after aerosolization of dihydroergocornine suggests that further studies of adrenergic blocking agents by this route of administration should be carried out.

\section{SUM MARY}

Dihydroergocornine in intravenous doses of from 0.25 to $0.75 \mathrm{mg}$. was administered to a group of 12 subjects with bronchial asthma. Protective tests were performed by measuring the change in the vital capacity and maximum minute ventilation, due to histamine and methacholine before and after the administration of dihydroergocornine.

In eight cases protection of 50 per cent or more resulted and no serious side reactions were experienced. The results suggest an explanation for the hyper-responsiveness of the tracheobronchial tree to histamine and cholinergic drugs in asthmatic subjects. The clinical implications are discussed.

\section{BIBLIOGRAPHY}

1. Curry, J. J., The action of histamine on the respiratory tract in normal and asthmatic subjects. J. Clin. Invest., 1946, 25, 785.

2. Curry, J. J., Comparative action of acetyl-beta-methyl choline and histamine on the respiratory tract in normals. Patients with hay fever, and subjects with bronchial asthma. J. Clin. Invest., 1947, 26, 430.

3. Curry, J. J., and Leard, S. E., The action of pilocarpine on the lungs in normal and asthmatic subjects. J. Lab. \& Clin. Med., 1948, 33, 585.

4. Curry, J. J., and Lowell, F. C., Measurement of vital capacity in asthmatic subjects receiving histamine and acetyl-beta-methyl choline. A clinical study. J. Allergy, 1948, 19, 9.

5. Curry, J. J., Fuchs, J. E., and Leard, S. E., Clinical implications of the effects of various anticholinergic agents in modifying the pulmonary response of asthmatic subjects to injected methacholine. Bull. New England Med. Center, 1948, 10, 164.

6. Curry, J. J., Fuchs, J. E., and Leard, S. E., Clinical and experimental studies with orthoxine in the treatment of bronchial asthma. J. Allergy, 1949, 20, 104. 
7. Rienhoff, W. F., Jr., and Gay, L. W., Treatment of intractable bronchial asthma by bilateral resection of the posterior pulmonary plexus. Arch Surg., 1938, 37, 456.

8. Carr, D., and Chandler, H., Dorsal sympathetic ganglionectomy for intractable asthma. J. Thoracic Surg., 1948, 17, 1.

9. Whitelaw, G., Fuchs, J. E., and Curry, J. J. Work in progress.

10. Bluntschli, H. J., and Goetz, R. H., The effect of ergot derivatives on the circulation in man with special reference to two new hydrogenated compounds (dihydroergotamine and dihydroergocornine). Am. Heart J., 1948, 35, 873.

11. Reichert, P., Oxygen utilization as an index of respiratory efficiency. A clinical device for its determination. J. Aviation Med., 1936, 7, 63.

12. Cournand, A., Richards, D. W., Jr., and Darling, R. C., Graphic tracings of respiration in study of pulmonary disease. Am. Rev. Tuberc., 1939, 40, 487. 